Pediat. Res. 3: 51-59 (1969)

Glomerular filtration rate

glucose $\mathrm{Tm}$ growth, kidney

kidney

renal function

\title{
Character of Function and Size in Kidney During Normal Growth of Rats
}

\author{
D. Potrer, A.Jarrah, T.Sakai, J.Harrah and M.A. Holliday ${ }^{[43]}$ \\ Department of Pediatrics, University of California School of Medicine, \\ and the San Francisco General Hospital, San Francisco, California, USA
}

\begin{abstract}
Extract
During normal growth in male rats (3 weeks to 3 months of age) weighing from $50-400 \mathrm{~g}$, kidney weight and glomerular filtration rate (GFR) increased at slower rates than did body weight; in contrast, the rate of increase in kidney weight and glomerular filtration rate were the same, and the ratio of GFR:g kidney weight was constant after 4-5 weeks of age. The ratio of maximal glucose reabsorption $\left(\mathrm{Tm}_{\mathrm{G}}\right)$ to GFR increased only slightly with growth. Na-K-dependent ATPase activity/ mg light microsomal protein from kidney cortex and $\mathrm{QO}_{2}$ did not change during growth. Kidney growth up to $200 \mathrm{~g}$ body weight at 16 weeks of age was due more to an increase in cell number; beyond then it was due more to an increase in cell size. The pattern of function-structure relation during growth differed from that observed in kidney hypertrophy secondary to uninephrectomy. It was not specifically determined from cell number or size but from some property proportional to total protein mass or to the product of cell number and cell mass.
\end{abstract}

\section{Speculation}

Tubular functions of the nephron during growth increase in proportion to each other and in proportion to total renal mass. This pattern of increase differs in several respects from that which occurs following uninephrectomy. The inference is that growth response differs in fundamental biological character from the hypertrophy response.

\section{Introduction}

During normal growth, renal function does not increase in proportion to body weight (BW) but does increase approximately in proportion to surface area or metabolic activity of the body [12, 24, 30, 33, 37]. It is also known that kidney weight (KW) does not increase in proportion to body size but does increase approximately in proportion to surface area. RuBin et al. [30] found that glomerular filtration rate (GFR) measured in children over a considerable age and size span correlated well with surface area after one year of age but correlated even better with KW, even though the latter was estimated from standard tables of organ weights to body weight. This finding and other available evidence suggest that GFR/g kidney is relatively constant during growth. This inference contrasts to the findings in species differing in size in which GFR/g kidney has been shown to vary inversely with size. The ratio was highest in rats, intermediate in dogs, and lowest in man when these three species were compared [11]. 
There are no studies, however, in which sufficient dircct comparisons have been made to develop a mathematical relation between kidney function (other than urea clearance), kidney size, and BW. The kidney is uniquely suited for this comparison because functional capacity can be approximated from the measurement of GFR. Although GFR alone does not represent kidney work, the reabsorption of sodium $\left(T_{\mathrm{Na}}\right)$ from glomerular filtrate is directly proportional to GFR. GFR and $\mathrm{T}_{\mathrm{Na}}$ have been shown to be proportional to in viro renal oxygen consumption $\left(\mathrm{V}_{\mathrm{O}_{2}}\right)[4,19]$. Consequently, GFR, $\mathrm{T}_{\mathrm{Na}}$, and $\mathrm{V}_{\mathrm{O}_{2}}$ can be used interchangeably as measures of kidney function under most conditions. A further analysis of functional organization as related to structural growth can be obtained by comparing other measures of function to $\mathrm{KW}$ during growth. The tubular maximum for glucose reabsorption $\left(\mathrm{Tm}_{G}\right)$ has been shown to correlate with proximal volume indirectly [28] and to increase to a greater degree than GFR during the hypertrophy response to uninephrectomy or $3 / 4$ nephrectomy [16]. Since it is impractical to measure $\mathrm{V}_{\mathrm{O}_{2}}$ in the rat, it can only be inferred either from $\mathrm{T}_{\mathrm{Na}}$ or from in vitro oxygen consumption [5, 35]. KATZ and EPSTErN [13] have reported that $\mathrm{Na}-\mathrm{K}$-dependent adenosine triphosphatase (Na-K, ATPase) activity increases during hypertrophy of the kidney in relation to kidney protein. In the present study, these variables were measured during normal growth. In addition, kidney protein and DNA were measured to provide more details of cellular growth in relation to these functions.

\section{Methods}

Male rats of the Sprague-Dawley strain, weighing from $50-400 \mathrm{~g}$ and from 3 weeks to 3 months in age, were studied. A small group of Fisher strain inbred rats having a slower gain in body weight with age was also studied for comparison.

GFR was determined in 68 rats by the constant infusion technic using clearance of inulin $\left(\mathrm{C}_{\mathrm{in}}\right)$ or sodium iothalamate $\left(\mathrm{C}_{\mathrm{To}_{0}}\right)$ to measure GFR. The rats were lightly anesthetized with $3-6 \mathrm{ml} / 100 \mathrm{~g} \mathrm{BW}$ of $12 \%$ ethanol in water given by gavage in two doses $30 \mathrm{~min}$ utes apart. They were placed in a plastic or metal restraining cage in the prone position and infusion was started through a tail vein. A priming dose of $12.5 \mathrm{mg}$ inulin $/ 100 \mathrm{~g} \mathrm{BW}$ was followed by an infusion of $5 \%$ glucose in $0.2 \%$ saline containing inulin sufficient to maintain the concentration of inulin in plasma of approximately $0.5 \mathrm{mg} / \mathrm{ml}$ and to ensure a urine flow between $0.1-0.5 \mathrm{ml} / \mathrm{min}$, depending on the size of the rat $[3,10]$.

Urine was collected in a funnel placed beneath the perineum. Collections were made either from spontancous voidings, which were timed, or from an indwelling suprapubic catheter. Between 2-5 ml of urine was collected in each of three periods; when spontaneous voidings were used, at least three voidings were collected for each period. An equilibration period of one hour preceded any collection for clearances. At midpoints, blood was collected from a foot vein into capillary tubes $(0.1-0.3 \mathrm{ml} / \mathrm{sample})$. Levels of plasma inulin and $\mathrm{C}_{\text {in }}$ of two successive periods had to agree within $10 \%$ to be accepted for the study.

At the end of the clearance procedure, animals were reweighed and then sacrificed to obtain KW. The kidney was dried to constant weight and dry kidney weight $(\mathrm{DKW})$ and water content calculated. In later experiments, sacrifice was deferred until the day following because it became apparent that the infusion procedure sometimes increased the water content of the kidneys transiently, although it did not affect the dry weight.

When $\mathrm{C}_{\text {Io }}$ was measured, 2-3 $\mu \mathrm{c}$ of I $^{131}$ iothalamate/ $100 \mathrm{~g} \mathrm{BW}$ was given as a priming dose; sufficient iothalamate was added to the infusion to provide 10,000 counts/3 min/0.02 ml plasma.

$\mathrm{Tm}_{\mathrm{G}}$ was measured with GFR ( $\mathrm{C}_{\mathrm{To}}$ ) in two groups of rats having an average $\mathrm{BW}$ of 173 and $350 \mathrm{~g}$, respectively. The priming dose of glucose in both groups was $100 \mathrm{mg} / 100 \mathrm{~g} \mathrm{BW}$ given as $10 \%$ glucose in water. The sustaining infusion contained $5-7 \%$ glucose in $0.2 \%$ saline given at a rate to maintain a concentration of plasma glucose between $4-6 \mathrm{mg} / \mathrm{ml}$. In these studies, results were accepted if the measured GFR met the criteria previously cited. TmG varied in successive periods by as much as $15 \%$ in some of the accepted instances.

Clcarance of para-aminohippurate $\left(\mathrm{C}_{\mathrm{PAH}}\right)$ was measured in one group weighing $298 \mathrm{~g}$; in this group, hyperglycemia was avoided and only small amounts of glucose were given. The priming dose of PAH was $0.75 \mathrm{mg} / 100 \mathrm{~g} \mathrm{BW}$ and the sustaining dose was suffcient to maintain a plasma level of $0.35 \mathrm{mg} / \mathrm{ml}$.

Inulin was measured by the method of WALSER $\mathrm{et}$ al. [36], glucose by the use of the Glucostat ${ }^{\circledR}$ glucose oxidase method, and PAH by the method of Sмгтн [31]. Iothalamate $\mathrm{I}^{131}$ was quantified by counting diluted urine and plasma in a well detector to obtain the $\mathrm{U}: \mathrm{P}$ ratio for calculating clearance. Ratios of $\mathrm{C}_{\mathrm{IO}_{0}}: \mathrm{C}_{\mathrm{in}}$ averaged 1.01 in 6 rats when simultaneous measurements were made.

Na-K-dependent ATPase activity was measured as described by Katz and EPsTEIN [13] in four groups of rats averaging approximately 50, 90, 250 and $350 \mathrm{~g}$, respectively. Total ATPase activity was determined on the light microsomal fraction of homogenized cortex obtained and assayed in $5 \mathrm{ml}$ of incubation fluid con- 
taining $100 \mathrm{mM} \mathrm{NaCl}, 20 \mathrm{mM} \mathrm{KCl}, 10 \mathrm{mM}$ imidazole buffer, and $5 \mathrm{mM}$ of $\mathrm{MgCl}-\mathrm{ATP} / \mathrm{l}$. The reaction was started by adding Mg-ATP solution to prewarmed $\left(37^{\circ}\right)$ incubation media containing $0.2 \mathrm{ml}$ light microsomal fraction having 1-3 mg protein/ml. After five minutes, the reaction was terminated by adding $1 \mathrm{ml}$ ice cold $35 \%$ trichloracetic acid. The Na-K-dependent ATPase activity was calculated as the difference between total activity and that obtained in identical incubation media in which $\mathrm{Na}$ was substituted for $\mathrm{K}$. Activity was expressed as $\mu \mathrm{M}$ phosphorus/mg protein/ h. Protein in the microsomal fraction was determined by the method of Lowry [21].

Five groups of 10 rats, each with an average weight of $50,100,200,300$ and $400 \mathrm{~g}$, respectively, were studied. One kidney was excised, weighed in a torsion balance, and quickly immersed in chilled KrebsRinger phosphate buffer medium at $\mathrm{pH} 7.4$; cortical slices ( $0.5 \mathrm{~mm}$ in thickness) were made with a StadieRiggs microtome. Slice weight was obtained after rapid blotting. Slices were added to a Warburg flask in $100 \%$ oxygen so that the flask contained approximately $50 \mathrm{mg}$ cortex in $2 \mathrm{ml}$ media. Oxygen consumption was measured for six successive 10-minute periods at $37^{\circ}$. The means of these values were calculated and used for subsequent computation.

The other kidney, or a kidney from a comparable rat, was also rapidly removed, weighed, and quartered. One quarter was rapidly frozen to $-20^{\circ}$ for subsequent determination of DNA. This portion was homogenized in 20:1 volume of ice-cold distilled water; DNA was precipitated with $0.2 \mathrm{~N}$ perchloric acid and hydrolyzed in $0.3 \mathrm{~N} \mathrm{KOH}$ for one hour [25]. DNA was measured using the indole color reaction when calf thymus DNA [41] served as a standard [2].

A second quarter of the kidney was weighed and dried to constant weight to determine the wet:dry ratio. A weighed aliquot of dry kidney was used to measure total nitrogen by the micro-Kjeldahl method.

\section{Biometric Analysis}

In comparing growth rates, log-log plots have been widely used to derive the exponential growth rate of a dependent variable upon an independent variable. The slope of such a log-log plot will be less than one if the dependent variable has a lower growth rate than the independent variable, equal to one if the growth rates of both variables are equal, and greater than one if the dependent variable is growing more rapidly than the independent variable.

The regression equations were derived by the method of least squares using an Olivetti-Programma 101. The following formulae were used in calculating the standard error of the estimate $\left(\mathrm{SE}_{\text {est }}\right)$ and Standard Error of the slope ( $\left.\mathrm{SE}_{\text {slope }}\right)$, respectively:

$$
\begin{aligned}
& \mathrm{SE}_{\text {est }}=\sqrt{1-\mathrm{r}_{\mathrm{xy}} \cdot \mathrm{N} \Sigma_{\mathrm{y}}{ }^{2}-\left(\Sigma_{\mathrm{y}}\right)^{2} / \mathrm{N}^{2}-2 \mathrm{~N}} \\
& \mathrm{SE}_{\text {slope }}=\sqrt{\mathrm{SE}_{\text {est }} / \Sigma(\mathrm{x}-\overline{\mathrm{x}})^{2}}
\end{aligned}
$$

When $\log$-log regressions were made, the logs were taken from tables to four places and lines of regression were derived. The arithmetic values have been plotted on $\log$-log coordinates to present visually the numerical relations.

\section{Results}

The individual values for BW, DKW, and GFR are noted in table $\mathrm{I}$. The regressions were derived for the $\log \mathrm{DKW}$ as a function of $\log \mathrm{BW} ; \log$ GFR as a function of $\log \mathrm{BW}$; and $\log$ GFR as a function of $\log \mathrm{DKW}$. The $\mathrm{SE}_{\text {slope, }}$ the correlation coefficient $(r)$, and the $\mathrm{SE}_{\text {est }}$ are summarized as follows:

\begin{tabular}{llllll}
\hline $\mathrm{f}(\mathrm{x})$ & $\mathrm{x}$ & slope $\pm \mathrm{SE}_{\text {slope }}$ & intercept & $\mathrm{r}$ & $\mathrm{SE}_{\text {est }}$ \\
\hline (1) $\log \mathrm{DKW}$ & $\log \mathrm{BW}$ & $0.716 \pm 0.014$ & -2.069 & 0.980 & \pm 0.039 \\
(2) $\log$ GFR & $\log \mathrm{BW}$ & $0.780 \pm 0.042$ & -1.051 & 0.911 & \pm 0.094 \\
(3) $\log$ GFR & $\log \mathrm{DKW}$ & $1.0785 \pm 0.056$ & +0.759 & 0.921 & \pm 0.089 \\
\hline
\end{tabular}

A plot of the data and the regression for log DKW as a function of BW (1) is illustrated in figure 1, and $\log$ GFR as a function of $\log \mathrm{DKW}(3)$ is illustrated in figure 2.

The slope of $\log$ GFR as a function of $\log$ DKW, 1.078 , is not significantly different from 1.0; consequently, the regression of GFR as a function of DKW is virtually linear (4) and when derived as a linear function is:
(4) $\mathrm{GFR}=5.44 \mathrm{DKW}+0.03$

The intercept $(0.03)$ is not significantly different from zero.

When there are no artifacts in measurement of WKW, the ratio of $\mathrm{KW}: \mathrm{DKW}$ appears constant, 4.18 (table IV). Hence, equation (4) can be further simplified as: (5) $\mathrm{GFR}=1.3 \mathrm{KW}$

The ratios of $\mathrm{Tm}_{G}$ to GFR were $3.04 \pm 0.47$ and $3.78 \pm 0.25$ in the first and second groups, respectively 
Table I. Individual values and group averages for body weight (BW), dry kidney weight (DKW) and glomerular filtration rate (GFR)

\begin{tabular}{|c|c|c|c|c|c|c|c|}
\hline & $\begin{array}{l}\text { BW } \\
(\mathrm{g})\end{array}$ & $\begin{array}{c}\text { DKW } \\
(\mathrm{g})\end{array}$ & $\begin{array}{c}\text { GFR } \\
(\mathrm{ml} / \mathrm{min})\end{array}$ & & $\begin{array}{l}\text { BW } \\
\text { (g) }\end{array}$ & $\begin{array}{c}\text { DKW } \\
(\mathrm{g})\end{array}$ & $\begin{array}{c}\text { GFR } \\
(\mathrm{ml} / \mathrm{min})\end{array}$ \\
\hline Group I: & 50 & 0.126 & 0.56 & Group IV: & 283 & 0.419 & 2.42 \\
\hline \multirow[t]{6}{*}{7 animals } & 51 & 0.126 & 0.53 & \multirow[t]{17}{*}{18 animals } & 283 & 0.418 & 1.80 \\
\hline & 58 & 0.167 & 0.64 & & 302 & 0.506 & 2.34 \\
\hline & 61 & 0.161 & 0.69 & & 304 & 0.547 & 2.25 \\
\hline & 65 & 0.181 & 1.00 & & 320 & 0.563 & 3.46 \\
\hline & 73 & 0.162 & 0.72 & & 330 & 0.476 & 2.01 \\
\hline & 73 & 0.196 & 0.82 & & 330 & 0.552 & 3.70 \\
\hline Mean $\pm \mathrm{SD}$ & $61.6 \pm 9.4$ & $0.160 \pm 0.026$ & $0.71 \pm 0.16$ & & 335 & 0.546 & 3.05 \\
\hline Group II: & 100 & 0.232 & 1.12 & & 336 & 0.602 & 3.68 \\
\hline \multirow{11}{*}{12 animals } & 100 & 0.236 & 1.18 & & 345 & 0.560 & 3.31 \\
\hline & 100 & 0.232 & 1.56 & & 350 & 0.478 & 2.76 \\
\hline & 105 & 0.218 & 1.56 & & 350 & 0.500 & 2.08 \\
\hline & 115 & 0.278 & 1.64 & & 350 & 0.578 & 3.26 \\
\hline & 120 & 0.260 & 1.00 & & 350 & 0.562 & 4.33 \\
\hline & 120 & 0.258 & 1.00 & & 350 & 0.474 & 2.89 \\
\hline & 125 & 0.262 & 1.36 & & 354 & 0.540 & 1.97 \\
\hline & 130 & $\begin{array}{l}0.262 \\
0.292\end{array}$ & 1.54 & & 355 & 0.656 & 3.48 \\
\hline & 130 & $\begin{array}{l}0.292 \\
0.320\end{array}$ & 1.40 & & 358 & 0.495 & 4.04 \\
\hline & 130 & $\begin{array}{l}0.320 \\
0.284\end{array}$ & $\begin{array}{l}1.84 \\
1.62\end{array}$ & $\underline{\text { Mean }} \pm \mathrm{SD}$ & $333 \pm 24$ & $0.526 \pm 0.061$ & $2.93 \pm 0.77$ \\
\hline & 130 & 0.256 & 1.66 & \multirow{16}{*}{$\begin{array}{l}\text { Group V: } \\
17 \text { animals }\end{array}$} & 360 & 0.626 & 3.46 \\
\hline Mean $\pm \mathrm{SD}$ & $117 \pm 12$ & $0.261 \pm 0.029$ & $1.46 \pm 0.25$ & & 360 & 0.530 & 2.30 \\
\hline Group III: & 169 & 0.351 & 1.39 & & $\begin{array}{l}360 \\
360\end{array}$ & $\begin{array}{l}0.589 \\
0.613\end{array}$ & $\begin{array}{l}3.97 \\
3.39\end{array}$ \\
\hline \multirow[t]{13}{*}{14 animals } & 171 & 0.334 & 1.76 & & 362 & 0.585 & 2.49 \\
\hline & 180 & 0.344 & 3.64 & & 374 & 0.732 & 2.78 \\
\hline & 180 & 0.404 & 2.22 & & 375 & 0.659 & 2.98 \\
\hline & 190 & 0.351 & 1.85 & & 380 & 0.602 & 3.28 \\
\hline & 195 & 0.382 & 1.92 & & 380 & 0.558 & 3.16 \\
\hline & 200 & 0.368 & 2.16 & & 380 & 0.631 & 3.27 \\
\hline & 200 & 0.380 & 2.40 & & 385 & 0.513 & 4.07 \\
\hline & 200 & 0.382 & 2.38 & & 390 & 0.646 & 3.18 \\
\hline & 215 & 0.460 & 2.96 & & 395 & 0.592 & 3.92 \\
\hline & 220 & 0.395 & 1.77 & & 400 & 0.598 & 2.84 \\
\hline & 220 & 0.516 & 3.16 & & 400 & 0.615 & 3.00 \\
\hline & 225 & 0.456 & 2.50 & & 400 & 0.654 & 3.58 \\
\hline & 230 & 0.448 & 1.86 & & 400 & 0.628 & 4.28 \\
\hline Mean \pm SD & $200 \pm 20$ & $0.398 \pm 0.053$ & $2.28 \pm 0.62$ & $\underline{\text { Mean }} \pm \mathrm{SD}$ & $381 \pm 16$ & $0.610 \pm 0.051$ & $3.29 \pm 0.55$ \\
\hline
\end{tabular}

Table II. Renal function in animals of two different sizes ${ }^{1}$

\begin{tabular}{|c|c|c|c|c|c|}
\hline No. of rats & $\begin{array}{c}\mathrm{BW}^{2} \\
\mathrm{~g}\end{array}$ & $\begin{array}{c}\mathrm{KW}^{3} \\
\mathrm{~g}\end{array}$ & $\begin{array}{l}\mathrm{GFR}^{4} \\
\mathrm{ml} / \mathrm{min}\end{array}$ & $\begin{array}{c}\operatorname{Tm}_{G^{5}}^{5} \\
\mathrm{mg} / \mathrm{min}\end{array}$ & $\mathrm{Tm}_{\mathrm{G}} / \mathrm{GFR}$ \\
\hline 9 & $173 \pm 37$ & - & $1.7 \pm 0.4$ & $5.17 \pm 1.03$ & $3.04 \pm 0.47$ \\
\hline 10 & $350 \pm 24$ & $1.30 \pm 0.13$ & $4.1 \pm 0.5$ & $15.3 \pm 2.2$ & $3.78 \pm 0.25$ \\
\hline \multicolumn{2}{|c|}{$\begin{array}{l}{ }^{1} \text { Values given are mean } \pm S D \text {. } \\
{ }^{2} \text { Body weight. }\end{array}$} & \multicolumn{2}{|c|}{$\begin{array}{l}{ }^{3} \text { Kidney weight. } \\
{ }^{4} \text { Glomerular filtration rate. }\end{array}$} & \multicolumn{2}{|c|}{${ }^{5}$ Glucose transport maximum. } \\
\hline
\end{tabular}




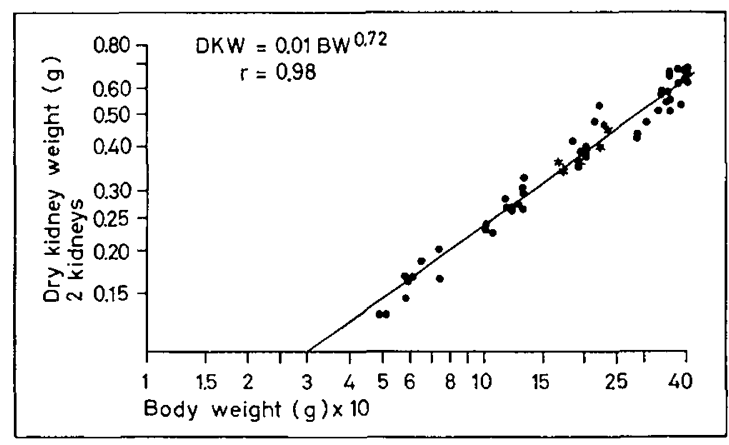

Fig. 1. Regression of dry kidney weight (DKW) upon body weight $(\mathrm{BW})$. The equation with the figure is in the exponential form. * Fisher inbred strain of rats. - Strague-Dawley rats.

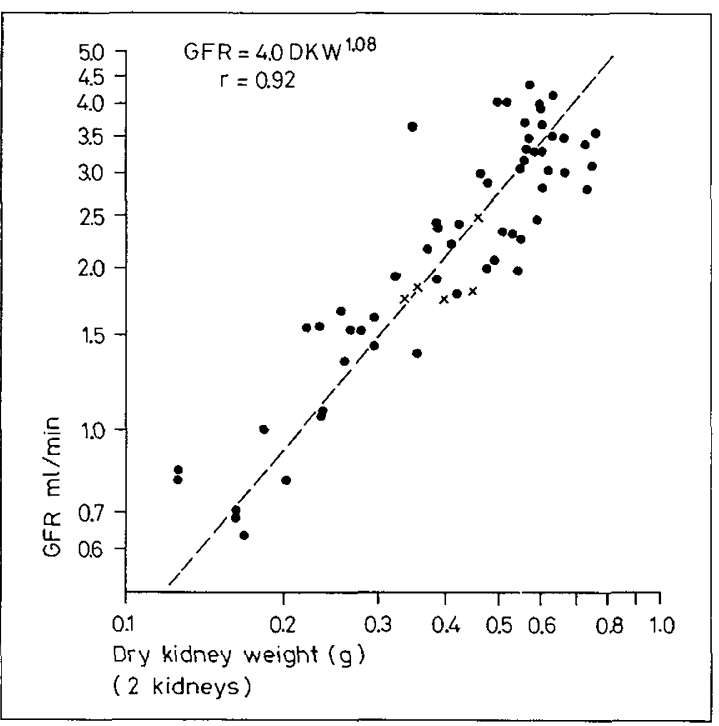

Fig. 2. Regression of glomerular filtration rate (GFR) upon dry kidney weight (DKW). The equation with the figure is the exponential form, whereas that cited in Equation 3 of text is in the $\log$ form as a linear equation. $\times$ Fisher inbred strain of rats. $\bullet$ Sprague-Dawley rats.

(table II). The differences in the ratios were statistically significant $(\mathrm{p}<0.05)$, but the magnitude of the differences in this comparison was small $(<20 \%)$. The $T \mathrm{~m}_{\mathrm{G}}: \mathrm{g} \mathrm{KW}$ was 2.9 in the second group when it could be calculated.

In the only group in which it was measured, the ratio of $\mathrm{CPAH}_{\mathrm{PA}}$ : GFR was 4.56 and the filtration fraction was $23 \%$. The BW for this group was $298 \pm 15 \mathrm{~g}$; the DKW (both kidneys) was $0.574 \pm 0.078 \mathrm{~g}$. Since extraction ratios could not be determined and true renal plasma flow could not be measured, comparative values at other weights were not obtained and the data are provided only for reference. From the hematocrit and $\mathrm{C}_{\mathrm{PAH}}$, the average blood flow was calculated to be $25.6 \mathrm{ml} / \mathrm{min}$.

Among the four groups of rats studied, Na-K-dependent ATPase/mg protein of the light microsomal fraction was not significantly different (table III).

The measurement of DNA and of $\mathrm{QO}_{2}$ permitted closer grouping of the data around specific weight ranges. Consequently, the results from five weight groups are expressed as means with SDs (table IV). The constant ratio of $\mathrm{KW}: \mathrm{DKW}$ is also noted. The protein calculated from total nitrogen, using a factor of 6.25 , is approximately $80 \%$ of the total DKW.

The cell number, when calculated from DNA content in $\mathrm{mg}$ (cell number $=\mathrm{DNA} \times 10^{9} / 6.2$ ) [18], indicates a progressive increase with growth, but at a rate slower than that characteristic of either $\mathrm{BW}$ or $\mathrm{KW}$. This is most readily visualized by comparing all data with that of the smallest group, the data from which were made equal to 1.0 . The data for subsequent weight groups are then expressed as multiples of 1.0 . The relative increase for $B W$ over the whole span is 6.92; for $\mathrm{KW}, 4.26$, and for DNA, 2.60.

These comparisons show that more than half of the increase of $\mathrm{KW}$ reflects an increase in cell number, while the balance, by definition, is due to an increase in cell mass. The relative values for $\mathrm{KW}$ and DNA for each weight group (table IV) are plotted against the relative values for BW using log-log coordinates (fig. 3). The slope of KW upon BW is very nearly that observed in Study I, 0.77 vs 0.72 . The rate of growth in cell number, however, is slower than that of $\mathrm{KW}$ and decreases with growth. An increase in cell size, as defined in this study, accounts for a smaller proportion of the increase in $\mathrm{KW}$ up to $200 \mathrm{~g} \mathrm{BW}$ and a somewhat larger proportion beyond that. This agrees with the results of others $[6,38]$.

Table III. Na-K-dependent ATPase activity of light microsomal fractions of kidney cortex in normal rats at different stages of growth ${ }^{1}$

\begin{tabular}{lccc}
\hline $\begin{array}{l}\text { No. of } \\
\text { rats }\end{array}$ & $\begin{array}{c}\mathrm{BW}^{2} \\
\mathrm{~g}\end{array}$ & $\begin{array}{c}\mathrm{KW}^{3} \\
\mathrm{~g}\end{array}$ & $\begin{array}{c}\text { Na-K ATPase } \\
\mu \mathrm{M} \mathrm{P} / \mathrm{mg} \\
\mathrm{protein} / \mathrm{h}\end{array}$ \\
\hline 6 & $50 \pm 2$ & $0.35 \pm 0.03$ & $28.6 \pm 4.4$ \\
5 & $93 \pm 4$ & $0.54 \pm 0.08$ & $25.2 \pm 8.9$ \\
5 & $256 \pm 6$ & $1.03 \pm 0.09$ & $22.3 \pm 3.9$ \\
6 & $352 \pm 29$ & $1.24 \pm 0.11$ & $26.4 \pm 3.9$ \\
\hline
\end{tabular}

1 Values given are mean $\pm S D$.

${ }^{2}$ Body weight.

${ }^{3}$ Kidney weight. 


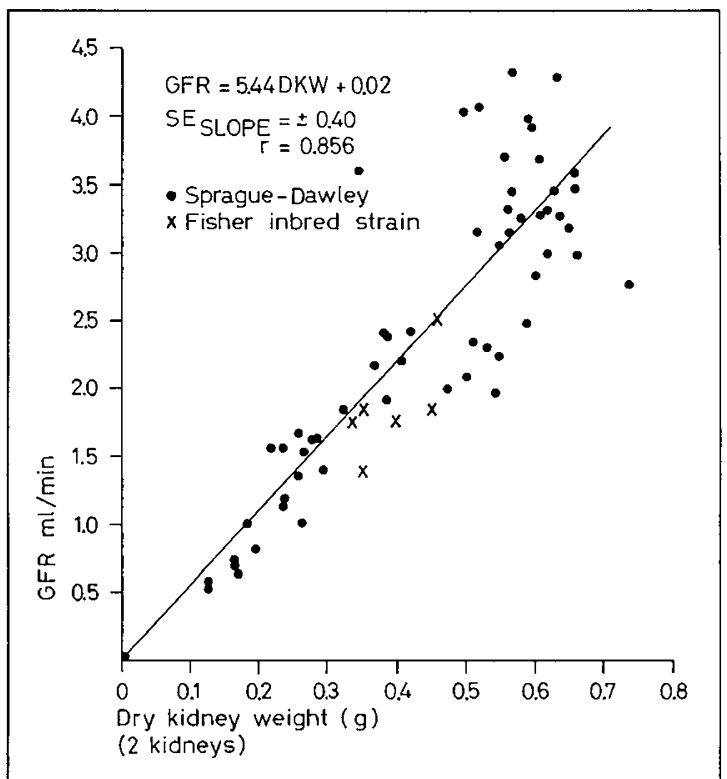

Fig.3. Arithmetic plot of glomerular filtration rate (GFR) upon dry kidney weight (DKW) using linear coordinates. Since the slope of the regression in figure 2 is not different from 1 , it can be assumed that this equation approaches a linear form.
The $\mathrm{QO}_{2}$ of cortical slices increased slightly with growth (table IV). The slight increase from $50-100 \mathrm{~g}$ BW and from $100-200 \mathrm{~g} \mathrm{BW}$ is not statistically significant. The $\mathrm{QO}_{2}$ of the $300 \mathrm{~g}$ group, however, is consistently higher by $10-15 \%$ than that for either the



Fig.4. Using the data from table $\mathrm{V}$, relative kidney weight $(\mathrm{KW})$ and relative cell number are plotted against relative body weight (BW). In this way, comparative rates of growth are illustrated. The break in the rate of increase in cell number is illustrated. Numbers in parentheses are actual body weights.

Table IV. Changes in rat kidney weight and composition

\begin{tabular}{|c|c|c|c|c|c|c|c|c|c|}
\hline \multirow{2}{*}{$\begin{array}{l}\text { No. of } \\
\text { rats }\end{array}$} & \multirow{2}{*}{$\begin{array}{l}\text { Age } \\
\text { wk }\end{array}$} & \multirow{2}{*}{$\begin{array}{c}\mathrm{BW}^{2} \\
\mathrm{~g}\end{array}$} & \multirow{2}{*}{$\begin{array}{c}\mathrm{WKW}^{3,4} \\
\mathrm{mg}\end{array}$} & \multirow{2}{*}{$\begin{array}{c}\mathrm{DKW}^{4,5} \\
\mathrm{mg}\end{array}$} & \multirow{2}{*}{$\begin{array}{l}\text { Wet:dry } \\
\text { ratio }\end{array}$} & \multicolumn{2}{|c|}{ Protein ${ }^{4}$} & \multirow{2}{*}{$\begin{array}{l}\text { Cell no. } \\
\quad \times 10^{6}, 7\end{array}$} & \multirow{2}{*}{$\begin{array}{c}\mathrm{QO}_{2} \mu \mathrm{l} / \mathrm{mg} / \mathrm{h} \\
\mathrm{DKW}\end{array}$} \\
\hline & & & & & & $\mathrm{mg}$ & $\% \mathrm{DKW}$ & & \\
\hline 10 & 3 & $\begin{array}{r}58 \\
\pm 7\end{array}$ & $\begin{array}{r}310 \\
\pm 26\end{array}$ & $\begin{array}{r}73.2 \\
\pm 6.9\end{array}$ & 4.25 & $\begin{array}{r}61.4 \\
\pm 7.1\end{array}$ & 84 & $\begin{array}{r}353 \\
\pm 34\end{array}$ & $\begin{array}{r}12.6 \\
\pm 1.0\end{array}$ \\
\hline 10 & 4.5 & $\begin{array}{l}110 \\
\pm 5\end{array}$ & $\begin{array}{r}525 \\
\pm 37\end{array}$ & $\begin{array}{r}127 \\
\pm 7\end{array}$ & 4.14 & $\begin{array}{r}98 \\
\pm 5\end{array}$ & 77 & $\begin{array}{r}495 \\
\pm 44\end{array}$ & $\begin{array}{r}13.9 \\
\pm 1.3\end{array}$ \\
\hline 10 & 7 & $\begin{array}{l}204 \\
\pm 6\end{array}$ & $\begin{array}{r}797 \\
\pm 77\end{array}$ & $\cdots$ & 4.17 & - & - & - & $\begin{array}{r}14.4 \\
\pm 1.4\end{array}$ \\
\hline 10 & & $\begin{array}{l}218 \\
\pm 6\end{array}$ & $\begin{array}{r}844 \\
\pm 62 \\
\end{array}$ & $\begin{array}{r}198 \\
\pm 14\end{array}$ & & $\begin{array}{r}166 \\
\pm 11 \\
\end{array}$ & 84 & $\begin{array}{r}762 \\
\pm 61 \\
\end{array}$ & - \\
\hline 10 & 10 & $\begin{array}{r}320 \\
\pm 16 \\
322 \\
\pm 19\end{array}$ & $\begin{array}{r}1151 \\
\pm 100 \\
1211 \\
\pm 123\end{array}$ & $\begin{array}{r}- \\
281 \\
\pm 28\end{array}$ & $\begin{array}{l}4.17 \\
- \\
4.21\end{array}$ & $\begin{array}{l}- \\
225 \\
\pm 25\end{array}$ & - & $\begin{array}{l}- \\
830 \\
\pm 97\end{array}$ & $\begin{array}{l}16.8^{6} \\
\pm 1.4\end{array}$ \\
\hline 10 & & $\begin{array}{r}398 \\
\pm 29\end{array}$ & $\begin{array}{r}1351 \\
\pm 108\end{array}$ & & 4.17 & & & & $\begin{array}{r}14.8 \\
\pm 2.1\end{array}$ \\
\hline 10 & 13 & $\begin{array}{r}402 \\
\pm 16 \\
\end{array}$ & $\begin{array}{r}1325 \\
\pm 96 \\
\end{array}$ & $\begin{array}{r}318 \\
\pm 25 \\
\end{array}$ & & $\begin{array}{r}249 \\
\pm 18 \\
\end{array}$ & 79 & $\begin{array}{r}917 \\
\pm 74 \\
\end{array}$ & \\
\hline \multicolumn{4}{|c|}{$\begin{array}{l}1 \text { Values given are mean } \pm \mathrm{SD} \text {. } \\
{ }^{2} \text { Body weight. } \\
{ }^{3} \text { Wet kidney weight. } \\
{ }^{4} \text { Right kidney only. }\end{array}$} & $\begin{array}{l}{ }^{5} \text { Dry ki } \\
{ }^{6} \text { In } 2 \text { o } \\
{ }^{7} \text { Calcul }\end{array}$ & $\begin{array}{l}\text { dney weigh } \\
\text { her studies } \\
\text { ated from I }\end{array}$ & $\begin{array}{l}\mathrm{O}_{2} \text { wa } \\
\mathrm{A} \text { cont }\end{array}$ & $\begin{array}{l}7 \text { and } 16.3 \\
{[18] .}\end{array}$ & $3 \mu \mathrm{l} / \mathrm{mg} / \mathrm{h}$ & respectively. \\
\hline
\end{tabular}


Table $V$. Comparison of changes in body weight, kidney size, and kidney cellularity ${ }^{1}$

\begin{tabular}{rcccc}
\hline $\begin{array}{l}\text { Actual } \\
\mathrm{BW}^{2} \mathrm{~g}\end{array}$ & BW $^{2}$ & WKW $^{3}$ & DNA & $\begin{array}{c}\text { Cell } \\
\text { size }^{4}\end{array}$ \\
\hline 58 & 1.00 & 1.00 & 1.00 & 1.00 \\
110 & 1.90 & 1.69 & 1.40 & 1.20 \\
218 & 3.76 & 2.72 & 2.16 & 1.26 \\
320 & 5.54 & 3.90 & 2.35 & 1.65 \\
402 & 6.92 & 4.26 & 2.60 & 1.65 \\
\hline
\end{tabular}

${ }^{1}$ Data for the smallest group are represented as 1.00 and for subsequent groups as a ratio to this value.

${ }^{2}$ Body weight.

${ }^{3}$ Wet kidney weight.

${ }^{4}$ WKW/DNA.

200- or the 400-g group. Although the significance of the finding is not apparent, this difference is confirmed by observations in two other groups of rats weighing. $300 \mathrm{~g}$.

\section{Discussion}

During normal growth, the increase in kidney function is proportional to the increase in total $\mathrm{KW}$. The rate of increase of each is slower than the rate of increase in $\mathrm{BW}$, a point inferred from several earlier studies $[9,12$, $22-24,30,32,33,37]$. $\mathrm{T}_{\mathrm{Na}}$ during growth is proportional to kidney protein and its rate is determined by some variable that, during normal growth, increases in proportion to kidney protein. $\left(\mathrm{T}_{\mathrm{Na}}\right.$, measured in only some of the experiments, was proportional to GFR and varied from $125-135 \mu \mathrm{Eq} / \mathrm{Na} / \mathrm{ml}$ GFR. $\mathrm{T}_{\mathrm{Na}}$ is used in this text when tubular reabsorption or renal work is being considered; GFR is used when the clearance or hemodynamic change is under consideration.) Since the number of nephrons does not change during growth in rats after they reach 50-100 g BW [15], it is obvious that $\mathrm{Na}$ reabsorption per nephron $\left(\mathrm{T}_{\mathrm{Na}}\right)$ increases in proportion to the increase in nephron mass. Oliver [27] noted that the nephron increased in size at different rates during normal growth in rats; however, the proximal volume increased in proportion to total kidney mass. Since about $70 \%$ of tubular reabsorption of $\mathrm{Na}$ occurs in the proximal tubule, this relation is not unnatural.

From Fetrerman's studies [7] and supplemental data [8], it was possible to demonstrate a correlation between proximal volume and $\mathrm{KW}$ in kidneys from children from birth to adolescence. The slope of the regression was consistent with proportional increases in proximal volume and $\mathrm{KW}$; however, the relatively low degree of correlation and a large standard error of the slope of the regression made it impossible to define a quantitative relation between the growth rate of proximal volume and of KW.

It would not be appropriate to infer from the findings in the present study that total kidney protein per se is the factor determining $\mathrm{T}_{\mathrm{Na}}$. Rather, some metabolic process resulting in $\mathrm{Na}$ transport must be the determinant. The rate-limiting step in this pathway during normal growth may be an enzyme or a membrane surface that is either coincidentally proportional to, or directly determined by, protein increase.

Since the ratio of $\mathrm{Tm}_{\mathrm{G}}$ to GFR is relatively constant and GFR is proportional to $\mathrm{KW}$ during growth, $\mathrm{Tm}_{\mathrm{G}}$ is also apparently proportional to KW during growth. We have already cited OLIVER's observation that proximal volume is proportional to KW during growth. Hence, our observations are in accord with the conclusion of Oliver and Bradlex et al. $[1,28]$, that $T \mathrm{~m}_{\mathrm{G}}$ is proportional to proximal volume.

The Na-K-dependent ATPase activity in the light microsomal fraction does not increase over the growth span studied. Katz and EPSTEIN [13] have described an increase in NA-K-dependent ATPase that corresponds to increases in $\mathrm{T}_{\mathrm{Na}}$ noted in renal hypertrophy. Further, the $\mathrm{T}_{\mathrm{Na}} / \mathrm{g} \mathrm{KW}$ also increased. The higher ATPase activity and the value for $\mathrm{T}_{\mathrm{Na}} / \mathrm{g} \mathrm{KW}$ noted with renal hypertrophy suggest that the pattern of growth in hypertrophy differs from that which occurs in normal growth. This is also suggested from OLIVER's work [27], for he reported that proximal volume increased more than KW in renal hypertrophy, in contrast to the proportional increases noted in normal growth. A similar inference is made in the present study when the ratios of $T m_{G}$ to GFR during normal growth are compared with those of KOLBERG [16] on dogs undergoing hypertrophy following uninephrectomy and $3 / 4$ nephrectomy. He noted that $T m_{G}$ increased much more than GFR with hypertrophy. Additional studies are in progress in our laboratory in order to compare $\mathrm{Tm}_{\mathrm{G}}$ during the growth of kidneys undergoing hypertrophy with kidneys having normal growth.

These data, which show that GFR/g KW is constant during growth, contrast to those reported earlier, when GFR/g KW varied inversely with body size among the three species compared-man, dog, and rat [11]. This finding reinforces the assumption that $\mathrm{T}_{\mathrm{Na}}$ is not a function of kidney protein per se, but is dependent during growth upon a variable that is proportional kidney protein.

The relative consistency of the ratio $\mathrm{Tm}_{\mathrm{G}}$ : GFR in the two groups studied is similar to that previously reported by others $[29,34]$ who, in rats, compared $\mathrm{Tm}_{\mathrm{G}}$ 
to GFR when GFR varied over a much greater range. Our observations are in agreement with the hypothesis proposed by Oliver [28] and Bradlex [1] that Tm $\mathrm{T}_{\mathrm{G}}$ is proportional to proximal volume, since both $T \mathrm{~m}_{\mathrm{G}}$ and proximal volume are proportional to $\mathrm{KW}$ during growth.

The relation of $\mathrm{QO}_{2}$, as measured in kidney slices, to $\mathrm{VO}_{2}$ measured in vivo has been the subject of much discussion [17, 35], but nodirect comparisons have been made. KREBS [17] has cited the variables that affect $\mathrm{QO}_{2}$. Our measurements of $\mathrm{QO}_{2}$ in rat kidney cortex, approximately $14 \mu \mathrm{M} / \mathrm{mg}$ weight/h using media similar to that which he used but with the reaction maintained at $37^{\circ}$ rather than at $40^{\circ}$, were approximately one-third his values, $-38.2 \mu \mathrm{M}$.

The $\mathrm{VO}_{2}$ of rat kidney has not been directly measured. It may be estimated in the normal state from $\mathrm{Na}$ reabsorption, because the relation of $\mathrm{T}_{\mathrm{Na}}$ to $\mathrm{VO}_{2}$ has been shown to be approximately $20 \mu \mathrm{Eq} \mathrm{Na} / \mu \mathrm{MO}_{2}$ $[4,14,19,20]$. The $\mathrm{T}_{\mathrm{Na}}$ in the rats in this study throughout growth, derived from GFR/g DKW/min (Equation 4), is $42 \mu \mathrm{Eq} \mathrm{Na} / \mathrm{mg} \mathrm{DKW} / \mathrm{h}$ (5.44 ml GFR/g $\mathrm{DKW} / \min \times 60 / 1000 \times 130 \mu \mathrm{Eq} / \mathrm{Na} / \mathrm{ml}$ GFR). The $\mathrm{VO}_{2}$, estimated from this and expressed in the same way as $\mathrm{QO}_{2}$, is $47 \mu \mathrm{I} \mathrm{O}_{2} / \mathrm{mg} \mathrm{DKW} / \mathrm{h}(42 \mu \mathrm{Eq} \mathrm{Na} \times 1 / 20 \mu \mathrm{Eq}$ $\mathrm{Na}$ per $\mu \mathrm{MO}_{2} \times 22.4 \mu \mathrm{M} / \mu \mathrm{l}$.) The predicted oxygen consumption, in the normal state, is $47 \mu \mathrm{l} \mathrm{O}_{2}$, and compares to the $\mathrm{QO}_{2}$ of 14 . The discrepancy may be due to the absence of luminal $\mathrm{Na}$ in the resting slice. When GFR was reduced in dogs to near zero, so that there was no luminal $\mathrm{Na}$ for transport, $\mathrm{VO}_{2}$ decreased to one-fourth the normal value [19]. If this corectly depicts the state of the slice, the predicted $\mathrm{VO}_{2}$ would equal approximately $12 \mu \mathrm{l} / \mathrm{mg} \mathrm{DKW} / \mathrm{h}$. This figure compares well with our observed values of $\mathrm{QO}_{2}$. If this comparison is valid, $\mathrm{QO}_{2}$ is reflecting renal oxygen consumption in a very abnormal condition. The figure for $\mathrm{QO}_{2}$ found by $\mathrm{KREBS}, 38.2 \mu \mathrm{l} / \mathrm{mg} \mathrm{DKW} / \mathrm{h}$, at $40^{\circ} \mathrm{C}$ is much closer to the value of $47 \mu$ l estimated indirectly. Nevertheless, $40^{\circ}$ is not the in vivo temperature and it seems unlikely that $\mathrm{Na}$ transport from lumen to plasma is proceeding in kidney slices incubating in vitro.

\section{Summary}

The relation of the increase in DNA to growth of the kidney conforms in pattern to that reported by others $[6,18,38]$. The range in $\mathrm{BW}$ in this study included larger rats-up to $400 \mathrm{~g}$. DNA increased to approximately 7 weeks of age in other studies as well as in this one. After that time, the increase in $\mathrm{KW}$ was due more to an increase in cell size (table V).

In spite of this shift in the character of growth, no shift in the pattern of functional increase was discerned.
Neither GFR, $\mathrm{T}_{\mathrm{Na}}, \mathrm{Tm}_{\mathrm{G}}$, nor Na-K-dependent ATPase activity changed in any relation to the shift in growth from cell division to increase in cell size. $\mathrm{QO}_{2}$ also did not change in any relation to cell number or size. This finding provides substantial evidence that change in function during growth is dictated neither by cell size nor by cell number but by some variable that can increase either as a function of cell number or size and is proportional to kidney protein during normal growth.

\section{References and Notes}

1. Bradley, S.E.; Laragh, J.H.; Wheeler, H.O.; MacDowell, M. and Orrver, J.: Correlation of structure and function in the handling of glucose by the nephrons of the canine kidney. J. clin. Invest. 40: 1113 (1961).

2. Ceriotti, J.: A microchemical determination of desoxyribonucleic acid. J.biol.Chem. 198: 297 (1952).

3. Cotlove, E.: Simple tail vein infusion method for renal clearance measurements in the rat. J.appl. Physiol. 16: 764 (1961).

4. Crosley, A.P., Jr.; Castillo, C. and Rowe, G.G.: The relationship of renal oxygen consumption to renal function and weight in individuals with normal and diseased kidneys. J. clin. Invest. 40: 836 (1961).

5. Davies, M.: On body size and tissue respiration. J. Cell. comp. Physiol. 57: 135 (1961).

6. Enesco, M. and Le Blond, C.P.: Increase in cell number as a factor in the growth of the organs and tissues of the young male rat. J.Embryol.exp. Morph. 10: 530 (1962).

7. Fetrerman, G.H.; Shuplock, N.A.; Philipp, F.J. and GREGG, H.S.: The growth and maturation of human glomeruli and proximal convolution from term to adulthood. Pediatrics 35: 601 (1965).

8. Fetterman, G.H.: Unpublished observations (1967).

9. Hatar, S.: On the weights of the abdominal and the thoracic viscera, the sex glands, ductless glands and the eyeballs of the albino rat according to body weight. Amer.J.Anat. 15: 87 (1913-14).

10. Holliday, M.A. and Egan, T.J.: Changes in GFR and $\mathrm{C}_{\mathrm{H}_{2} \mathrm{O}}$ before and after repair of $\mathrm{K}$ deficiency in rats. Amer.J. Physiol. 202: 773 (1962).

11. Holliday, M.A. and EGAN, T.J.: Renal function in man, dog and rat. Nature (Lond.) 193: 748 (1962).

12. Holten, C.: The dependence of the normal kidney function on the size of the body. Acta paediat. 12: 251 (1932). 
13. Katz, A. I. and Epstern, F. H.: The role of sodiumpotassium-activated adenosine triphosphatase in the reabsorption of sodium by the kidney. J.clin. Invest. 46: 1999 (1967).

14. Kill, F.; AukLand, K. and Refsum, H. E.: Renal sodium transport and oxygen consumption. Amer. J. Physiol. 201: 511 (1961).

15. Kirtelson, J.A.: The postnatal growth of the kidney of the albino rat, with observations of an adult human kidney. Anat. Rec. 13: 385 (1917).

16. Kolberg, A.: Relations of renal tubular and glomerular function as influenced by $75 \%$ reduction of nephron number. Scand.J. clin. Lab. Invest. 11: suppl. 41 (1959).

17. KREBS, H.A.: Body size and tissue respiration. Biochem. Biophys. Acta 4: 249 (1950).

18. Kurnick, N.B.: Cytochemical studies on the kidney. I. Role of cell multiplications in normal growth (kidney). J. exp. Med. 94: 373 (1951).

19. Lassen, N.A.; Munck, O. and Thaysen, J.H.: Oxygen consumption and sodium reabsorption in the kidney. Acta physiol.scand. 51: 371 (1961).

20. Leaf, A. and Dempsey, E.: Some effects of mammalian neurohypophyseal hormones on metabolism and active transport sodium by the isolated toad bladder. J. biol. Chem. 235: 2160 (1960).

21. Lowry, O.H.; Rosebrough, N.J.; Farr, A.L. and Randall, R.J.: Protein measurement with the Folic phenol reagent. J.biol. Chem. 193: 265 (1951).

22. MAcKAy, E.M.: Kidney weight, body size and renal function. Arch.intern. Med. 50: 590 (1932).

23. MACKAy, L.L. and MAGKAy, E.M.: Factors which determine renal weight (rats). II.Age. Amer. J. Physiol. 83: 191 (1928).

24. McIntosh, J.F.; Moller, E. and Van Slyke, D. D.: Studies of urea excretion. III. The influence of body size on urea output. J.clin. Invest. 6: 467 (1928).

25. Munro, H.N. and Fleck, A.: Recent developments in the measurement of nucleic acids in biological materials. Analyst 91:78 (1966).

26. New, M.; MaNamara, H. and Kretchmer, N.: Accumulation of para-aminohippurate by slices of kidney from rabbits of various ages. Proc. Soc. exp. Biol., N.Y. 102: 558 (1959).

27. Oliver, J.: New directions in renal morphology: A method, its results and its future. Harvey Lect. 40: 102 (1945).

28. Oliver, J. and MAaDoweld, M.: Structural and functional aspects of the handling of glucose by the nephrons and the kidney and their correlation by means of structural-functional equivalents. J. clin. Invest. 40: 1093 (1961).

29. Robson, A.M.; SRivastava, P.L. and Bricker, N.S.: The influence of saline loading on renal glucose reabsorption in the rat. J.clin. Invest. 47: 329 (1968).

30. Rubin, M. I.; Bruck, E. and RApoport, M.: Maturation of renal function in childhood: Clearance studies. J.clin. Invest. 28: 1144 (1949).

31. Sмrтн, H.W.: Principles of renal physiology, N.Y. (Oxford Univ. Press, Oxford 1956).

32. Stewart, G.N.: Possible relations of the weight of the lungs and other organs to body weight and surface area (in dogs). Amer. J. Physiol. 58: 45 (1921).

33. TAYloR, F.B.; DRURY, D. and ADDIs, T.: The regulation of renal activity. VIII. The relation between the rate of urea excretion and the size of the kidneys. Amer.J. Physiol. 65: 55 (1923).

34. Van Liew, J.; Deetjen, P. and Boylan, J.W.: Glucose reabsorption in rat kidney, dependence on glomerular filtration. Pflügers Arch.ges. Physiol. 295: 232 (1967).

35. Von Bertalanffy, L. and Pirozynski, W.J.: Tissue respiration and body size. Science 113: 599 (1951).

36. Walser, M.; Davidson, D.G. and Orloff, J.: The renal clearance of alkali-stable inulin. J.clin. Invest. 34: 1520 (1955).

37. West, J. R.; Smith, A.W. and Chasis, H.: Glomerular filtration rate, effective renal blood flow and maximal tubular excretory capacity in infancy. J.Pediat. 32: 10 (1948).

38. Winick, M. and Noble, A.: Quantitative changes in DNA, RNA, and protein during prenatal and postnatal growth in the rat. Develop. Biol. 12: 451 (1965).

39. Zumoff, B. and Pachter, M.R.: Studies of rat kidney and liver growth using total nuclear counts. Amer.J. Anat. 114: 479 (1964).

40. Glofil ${ }^{\circledR}$, Abbot Laboratories, North Chicago, Illinois.

41. Sigma Chemical Co., St. Louis, Missouri.

42. This work was supported in part by USPHS Grants Nos.HD 00182 and AM 11595.

43. Requests for reprints should be addressed to MALcolm A.Holliday, M.D., Department of Pediatrics, University of California, San Francisco Medical Center, San Francisco, Cal. 94122 (USA). 